\title{
Corporate Governance, Intellectual Capital and Firm Performance
}

\author{
Abdul Basyith ${ }^{1, *}$ \\ ${ }^{1}$ Faculty of Economics and Business, University of Muhammadiyah Palembang, Indonesia \\ *Correspondence: Faculty of Economics and Business, University of Muhammadiyah \\ Palembang, Indonesia. Tel: 62-711 -513-022. E-mail: basyith_feump@yahoo.com
}

Received: December 3, 2015 Accepted: January 24, 2016 Published: March 8, 2016

doi:10.5296/rae.v8i1.8675 URL: http://dx.doi.org/10.5296/rae.v8i1.8675

\begin{abstract}
This paper investigates the impact of corporate governance and intellectual capital on firm performance in Indonesian-listed firms. Using a balanced-panel of 120 Indonesian-listed firms, this study employs a balanced panel method, using non linier IV 2SLS and non linier IV-GMM. All variables, apart from commissioners, directors, education and capital employed efficiency exhibit a non significant impact on Tobins' $Q$, while all variables are statistically non significant for ROA. The findings are less conclusive than that of previous studies in developed countries. This study provides recent evidence for the corporate governance and intellectual capital in affecting firm peformance of listed-firms in Indonesian Stock Exchange. Though most listed-firms in Indonesia is owned by group or family, the appointment should be strictly complied to the regulations set, as current evidence indicates that independent commissioners and directors have no impact on firm performance, hence an awareness of good corporate governance conduct should be massively disseminated.
\end{abstract}

Key words: corporate governance, intellectual capital, firm value, Indonesia 


\section{Introduction}

Corporate governance is a set of mechanisms, processes and relations by which firms are controlled and directed that is arranged to accomplish firm's objectives. Corporate governance has became popular in Indonesia when many firms are experiencing insolvency during the economic and the financial crisis in 1997-1998 period, and most people assumed that the problems encountered by large corporations are caused by misconduct of management such as the lack of transparency in financial reporting. The case of financial reporting fraud and overvalued shares reporting fraud that have entangled some private audit institutions is occured at PT Lippo Bank, PT Kimia Farma, PT Texmaco and PT Cibinong (Prassetyantoko, 2008). Indeed, the corporate governance misconduct is inseparable from the responsibility of firm's management in managing the company neglected the principles of corporate governance such as transparency, accountability, responsibility, independency and fairness, and it is therefore necessary to continuously disseminate it. Further, the government has also participated actively in supporting good corporate governance conduct by enacting corporate governance regulations. Moreover, firms are also rated in accord with the corporate governance conduct compliance established by the governement, and this rate is aimed at motivating firms to intensify corporate governance conduct and to escalate their firm performance. Nevertheless, there are few firms that did not comply to the corporate governance conduct, for example, PT. Kimia Farma Tbk., in 2002 and PT Indofarma in 2004 manipulated earnings management by increasing their net profit to $\$ 32.7$ billion and $\mathrm{Rp} 28.870$ billion from their original profit as a result of overvalued of in-process inventory and it led the cost of goods sold to be undervalued (Prassetyantoko, 2008).

Ineffectiveness of management that is derived from conflict of interest between principal and agents will lead to inefficiency that may disturb firm's achievement and firm's objective. Not only has the corporate governance misconduct occured in the state-owned enterprises, but it has also occured in some non-government listed-firms, for example (1) PT Bank Duta in the 1990s and PT Lippo Tbk in 2001 are charged with financial reporting fraud, (2) PT Texmaco also performed manipulation on master settlement acquisition agreement (MSAA), (3) PT Indomobil performed buy back transaction of asset (Prassetyantoko, 2008). Financial scandals in US (Lockheed Corporation, 1976; ZZZZ Best, 1986; MiniScribe, 1989; Phar-Mor, 1992; Informix Corporation, 1996; Sybase, 1997; Cendant, 1998; Waste Management, Inc., 1999; MicroStrategy, 2000; Unify Corporation, 2000; Computer Associates, 2000; Xerox, 2000; Enron, 2001; Adelphia, 2002; AOL, 2002; Bristol-Myers Squibb, 2002; Freddie Mac, 2002; Kmart, 2002; Merck \& Co., 2002; Merrill Lynch, 2002; Royal Ahold, 2003; Chiquita Brands International, 2004; Bernard L. Madoff Investment Securities LLC, 2008; Lehman Brothers, 2008; Autonomy Corporation, 2012) have occurred since the 1970s in which it rendered a negative impact both financially and non-financially for the firm, such as poor corporate image.

Financial scandals also occured in some other developed countries, for example; Anglo Irish Bank (2008) occured in Ireland, Penny Stock Scam (2006) and Satyam Computer Services (2009) occured in India, Nortel (2003) and Sino-Forest Corporation (2011) occured in Canada, Olympus Corporation (2011) in Japan, Parmalat (2003) occured in Italy, Global 
Crossing (2002) and Tyco International (2002) occured in Bermuda, Nugan Hand Bank (1980) and One.Tel (2001) occured in Australia, Lernout \& Hauspie (2000) occured in Belgium, Swissair (2001) occured in Switzerland, and Barlow Clowes (1988), Polly Peck (1990), and Bank of Credit and Commerce International (1991) occured in England (Sumber: https://en.wikipedia.org/ wiki/Accounting_scandals). Some phenomenal financial scandals will significantly affect the whole economy, for example; Financial scandals which involved Merryl Linch in 2002 and Lehman Brothers in 2008 caused a significant negative impact on the economy of the United States as well as other countries who had trade relations with US (source: http://en.wikipedia.org/wiki/Subprime_crisis_impact_timeline). Scandals that happened in some developed countries involved internal management dealing with financial and accounting matters. They mostly provided misstatement of financial practices, inflated revenues and understated sales or earnings, and in fact, the misconduct occured is apparently supported by insider.

There are differences in financial scandals' motives occurred in developed countries compared to Indonesia. Large companies in the developed countries generally performed financial reporting fraud because they want to earn a bonus if profit increases. In contrast, most Indonesian firms intended to evade taxes by providing two different financial statements (http://www.bumn.go.id). Although various financial scandals arising in the massive corporate governance campaigns; there are also some companies experiencing a significant positive effect from corporate governance compliance. For example, OCBC-NISP Bank has been established since 1941 and publicly traded since 2004, and they confirmed that corporate governance conduct has become one of the success keys in encountering financial crisis for decades. The OCBC-NISP Bank started to intensify corporate governance conduct formally in 2006 by commencing corporate governance documentation and improving the corporate governance conduct (http://swa.co.id/corporate/gcg/ocbc-nisp-menerapkan-gcg-sec ara-substansial). Not only OCBC-NISP Bank has implemented corporate governance guidelines, PT Bank Muamalat, PT Bank Mega and PT Adira Finance has also implemented it.

In 1992, Cadbury Committee released the concept of corporate governance, and it is known as the Cadbury Report. The Cadbury Report contains series of recommendations in governing the company's directors and accounting systems that can minimise risks and failures. The Cadbury Report was later adopted by the European Union, United States, World Bank and some other countries. Afterwards, the concept of corporate governance in various perspectives has developed rapidly. The theory underlying the concept of corporate governance has been started since 1932 in which Berle and Means proposed the theory of separation between ownership and management, thereafter in the 1970s, the issues regarding the management of the company in relation to the firm performance started to raise more concerns since Jensen and Meckling (1976) published a theory about principal and agent's conflict, and it is referred as agency problems.

Corporate governance is also associated with intellectual capital in which firms should report their intellectual capital. Firms that comply to the corporate governance guidelines should report their intellectual capital such as patent rights. Intellectual capital plays an important 
role in achieving firm's objectives and it also assures the firm's survival. For example, firms that conduct research and development program continuously have higher sustainable level compared to firms who do not. Edvinsson and Sullivan (1996), and Tayles, Pike and Sofian (2007) asserted that intellectual capital can increase the company's profits in which the company's profit is significantly affected by innovation and knowledge-intensive services that can ultimately increase shareholders' value. Furthermore, Edvinsson and Sullivan (1996) stated that the ability of the Microsoft in enhancing the value of the company is mainly due to their intangible intellectual capital.

Disclosure is a part of corporate governance's principle, and if intellectual capital is linked to corporate governance, therefore intellectual capital disclosure is one of vital parts in implementing the corporate governance mechanisms. Intellectual capital disclosure is a valuable information for investors to reduce uncertainty about the prospects of the company in future. Intellectual capital disclosure can facilitate accuracy assessment of the value of the company (Bukh, 2003), and in the end it will ultimately improve firm performance. An intense competition of business both nationally and globally along with growing number of listed-firms has driven management to be more effective and efficient in managing the firm. Firms who have higher compliance of corporate governance may attract more investors as corporate governance can be viewed as one of a firm's assets.

However, there are only few studies in Indonesia investigated the impact of corporate governance and intellectual capital on firm value. Particularly, only a few studies that investigate the impact of intellectual capital of firm performance used the concept consisting of four factors, human capital, structural capital, capital employed and innovation capital. Previous studies solely focused on the relationship between intellectual capital disclosure and firm performance. Moreover, the existing papers investigated this matter are solely focusing on specific sectors as it cannot capture the whole picture of industries, hence conclusions made is limited to the sector sample used. Furthermore, most previous studies in Indonesia had employed inappropriate method of analysis in which most studies neglected endogeneity problem that may arise, hence it may lead to biased estimates. Further, the absence of diagnostic testing/specification testing, such as outlier test, linearity test, endogeneity test and other tests, prior to method of analysis determination led to biased parameters. If the data is non-linear, but the equation model utilises a linear model, then the results yielded are biased estimates. Though, the corporate governance has been extensively campaigned in recent years by government and non-government institutions, cases which caused by ineffectiveness of corporate governance conduct considerably occured. Hence, this study fills those gap. In conclusion, this study focuses generally on the corporate governance and intellectual capital in Indonesia. Specifically we focus on how corporate governance and intellectual capital may add value to a firm and increase the wealth of the firm's owner. Therefore, we attempt here to answer this question: "How do corporate governance and intellectual capital affect firm value?" Commissioners, independent commissioners, directors, independent directors, ethnicity, graduate origin, qualifications and remunerations are employed as proxies to indicate the corporate governance. Human capital efficiency, structural capital efficiency, capital employed efficiency and innovation capital efficiency are employed as proxies to indicate 
intellectual capital.

\section{Literature Review}

\subsection{Corporate Governance and Firm Performance}

After the economic and financial crisis in Asia following a number of financial scandals occured in most large companies, hence the campaign of good corporate governance conduct is massively publicised either from independent institutions, government institustions and private firms. Not only have the government institutions and independent institutions involved in corporate governance matter by enacting regulations and monitoring of the goverment's regulations, the academics have began to raise concern in investigating the corporate governance conduct and its effect toward firms overall.

Previous studies on corporate governance and corporate value have been carried out in many countries. Agrawal and Knoeber (1996), Yermack (1996) Barnhart and Rosenstein (1998), Gompers, Ishii and Metrick (2003), and Brown and Caylor (2009) investigated the impact of corporate governance on firm value in the United States. Hanousek, Kocenda, and Novotny (2012, 2015) studied the corporate efficiency in Europe. Cheung, Connelly, Limphapayom and Zhou (2007) examined the existing enterprises in Hong Kong, Australia and the United Kingdom. Most previous research focused on the relationship between mechanisms of corporate governance and firm performance.

The results yielded in most previous studies are inconclusive since some studies yield a positive significant result (Hermalin and Weisbach, 1991, 2003; Dalton et al., 1999; Dehaene et al., 2001; Gompers et al., 2003; Brown and Caylor, 2009; Dittmar and Mahrt-Smith, 2007; Harjoto and Hoje, 2008), and some studies yield a negative significant result (Agrawal and Knoeber, 1996; Yermack, 1996; Klein, 1998; Bhagat and Black, 2002; Drakos and Bekiris, 2010), and other study yields non significant result (Schmid and Zimmermann, 2005).

Corporate governance mechanisms can be classified into five categories; board size, board demographics, board leaderships, board education and board evaluation. Board size consists of board of commissioners, independent commisioners, board of directors, independent directors, female directors, foreign directors and committe size. Board demographics consists of gender, age and ethnicity of director. Board leaderships consists of inside ownership, blockholder ownership and public ownership. Board education consists of qualifications and trainings of director. Board evaluation consists of years' experience, salary and directors' meeting frequency. As stated by Zahra and Stanton (1998) that the board of directors is an important and valuable instrument of a company where the directors can maximise the prosperity of the owner through an effective control over managerial activities. Ethnic diversity also broadens knowledge, idea and experience through the range of information resources of different cultural background among the board members (Hambrick, Cho and Chen, 1996). Further, cultural heterogeneity will also improve management performance as it shares ideas and makes decision based on various thinking. 
Moreover, corporate governance have been classified into four types, (1) the outsider system (market-centric model), (2) insider system (relationship-based model), (3) the transition system and, (4) the emerging governance system. United States and Britain adopted a system of market-centric model for corporate governance mechanisms. The main characteristics of this model are firms having dispersed ownership and there are strong legal protection to investors. Japan and Germany adopted the relational system-based model, where legal protection of investors is weaker than the market-centric models. Russia and most eastern European countries as well as other countries adopted a transition system and emerging governance systems for their corporate governance mechanisms. The main characteristics of these two models are firms having concentrated ownership and the legal protection of investors is weak and, the capital market is not fully developed.

Further, the fundamental of corporate governance is to solve agency problems. Jensen and Meckling (1976) stated that agency problems are crucial as a result of separation between ownership and management since management do not always behave in the best interest of owners. For such condition, the mechanisms of corporate governance both internally and externally plays an important role in minimising conflict between firms' owner (principal) and management (agents). Therefore, compensation and incentives are offered to board member or top executives to minimise conflicts (Dong and Ozkan, 2008). Compensation is regarded as important to (1) motivate top executives to work in line with the interests of firms' owner, (2) to recruit and retain managers who have a high quality (Anderson and Bizjak, 2003). The well-established good corporate governance framework will ultimately affect to easier financing access, low cost of capital, increase stakeholders' sympathy and improve a better firm performance (Claessens, Djankov, Fan and Lang, 2002), higher firm value (Gompers, Ishii and Metrick, 2003) and higher rate of return on investment and higher firm performance (Brown and Caylor, 2009).

There are few studies conducted in several countries in Asia and ASEAN countries such as China (Sami, Wang and Zhou, 2011), Hong Kong (Cheung, Stouraitis and Tan, 2010), India (Garg, 2007), Thailand (Connelly, Limphapayom and Nagarajan, 2012), Korea (Black and Kim, 2012), Malaysia (Shukeri, Shin and Shaari, 2012), and a mixture of some countries such as Korea, Malaysia, Indonesia, Thailand and Filifina (Mitton, 2001). Some studies yielded a positive significant results (Mitton, 2001; Cheung et al., 2010; Sami et al., 2011; Connelly et al., 2012; Black and Kim, 2012; Shukeri, Shin and Shaari, 2012;), and other study yielded a negative significant result (Garg, 2007). The absence of consistent results in Asian countries and ASEAN are caused by technical factors and non-technical factors.

Few studies of corporate governance and firm performance in Indonesia have been investigated in recent years (Mitton, 2001; Darmawati, Khomsyiah and Rahayu, 2005; Pudjiastuti and Mardiyah, 2007; Suherman, Rahmawati and Buchdadi, 2011; Herly and Sisnuhadi, 2011; Darmadi, 2011). Mitton (2001) examined the impact of corporate governance on corporate performance in several countries including Indonesia found that there is a significant impact of corporate governance on company performance. Darmawati, Khomsyiah and Rahayu (2005) found that there is no significant effect of the practice of good corporate governance on corporate performance as measured by Tobins' q, but it yielded a significant 
effect when measured by ROE. Pudjiastuti and Mardiyah (2007) investigated the effect directors' structure on corporate performance using the 150 companies listed on the Indonesia Stock Exchange with a study period of 2001 to 2005 . The results revealed that the size of the board directors and the number of women directors have a negative and significant effect on corporate value, but the number of independent directors has a positive and significant effect on corporate value. Suherman, Rahmawati and Buchdadi (2011) found a significant relationship between corporate performance and corporate governance mechanisms (independent directors and institutional ownership) on executive director's compensation. Herly and Sisnuhadi (2011) found a significant relationship between corporate governance and firm performance, but the results cannot be concluded because of the differences results of firm value. Furthermore, Herly and Sisnuhadi found that there is a positive significant relationship if it measured using accounting-based measured (ROA), and a negative significant relationship if it measured using mixed-based (accounting and market-based). Darmadi (2011) investigated the relationship between directors diversity (gender, age and nationality) and the value of the company. The results revealed that gender and age have a significant and negative effect on the value of the company. Diversity of citizenship exhibited non significant effect to the value of the company. Further, in the same year, Darmadi also investigated the relationship between educational qualifications of directors with the value of the company, and found that the educational qualifications of directors has a significant role in improving performance of the company. Not only that, Darmadi also confirmed that the directors who has educational qualifications from a prestigious university has a better performance than the directors who do not have such qualifications. Morevoer, in other study, Darmadi also found that female directors has a negative and significant effect on the firm performance both measured by accounting-based and market-based measured. Furthermore, Darmadi investigated the impact of the size of other directors (both director and commissioner) on firm performance, and found a positive and significant impact.

Finally, to answer the research question, and based on the previous study findings, hence, a series of testable hypothesis for corporate governance are derived as follow:

Carter Simkins \& Simpson (2003) and Coles, Daniel \& Naveen (2008) find a positive relationship between board size and firm performance, therefore this study hyphotesised that:

\section{Number of board commissioners has a positive impact on firm performance}

2. Number of board directors has a positive impact on firm performance

Agrawal and Knoeber (1996), Yermack (1996), Klein (1998), Bhagat and Black (2002) and Drakos and Bekiris (2010) find a negative relationship between independent board and firm performance, therefore this study hypothesised that:

\section{Independent commisioners has a negative impact on firm performance}

\section{Independent directors has a negative impact on firm performance}

Hambrick et al. (1996) and Carter et al. (2003) find a postive relationship between ethnic and firm performance, therefore this study hypothesised that: 
5. Ethnic has a positive impact on firm performance

Switzer and Huang (2007) and Chang, Dasgupta and Hilary (2010) find a postive relationship between qualifications and firm performance, therefore this study hypothesised that:

6. Graduate origin has a positive impact on firm performance

7. Education level (High School) has a negative impact on firm performance

8. Education level (Undergraduate) has a positive impact on firm performance

9. Education level (graduate) has a positive impact on firm performance

Aggarwal and Samwick (1999) and Dong and Ozkan (2008) find a postive relationship between remuneration and firm performance, therefore this study hypothesised that:

\section{Remuneration has a positive impact on firm performance}

\subsection{Intellectual Capital and Firm Performance}

Intellectual capital is one of important aspects in creating firm value by having firm's competitive advantage (Drucker, 1993). Not only intellectual capital plays an important role in determining firm value but it also viewed as firm's fundamental in determining firm' strength and growth in future (Choudhury, 2010). The relationship between intellectual capital and firm value has been investigated in many developed countries. Roos, Roos and Edvinsson (1998) investigated in England, Edvinsson and Malone (1997) investigated in Swedish, Bornemann (1999) investigated in Australia, Bontis (1998) investigated in Canada, Maditinos, Chatzoudes, Tsairidis and Theriou (2011) investigated in Greece and, Bassi and Buren (1999) investigated United States (US). Nevertheless, previous studies also focused in Asian countries, such as Taiwan (Chen, Cheng and Hwang, 2005), Hong Kong (Chan, 2009), Iran (Mehralian, Rajabzadeh, Sadeh and Rasekh, 2012), Singapore (Tan, Plowman and Hancock, 2007), Malaysia (Gan and Saleh, 2008), India (Mondal and Ghosh, 2012). However, most previous empirical evidence indicated that the relationship between intellectual capital and firm performance is relatively low, and it may be caused by the difficulty to form constructs that are related to measurement problems in which construct can not be identified and observed directly. Chen et al. (2005), Mehralian et al. (2012), Tan et al. (2007), Gan and Saleh (2008) and Maditinos et al. (2011) found a positive relationship between intellectual capital and firm performance. While Bornemann (1999) found a negative relationship between intellectual capital and firm performance. Further Mondal and Ghosh (2012), and Chan (2009) found inconclusive results. There are few studies conducted in Indonesia such as Kuryanto and Syaffrudin (2008) found there is no impact of intellectual capital on firm performance using 73 firms listed on the Indonesian Stock Exchange with period 2003 to 2005. While Ulum (2008) found a positive relationship between intellectual capital and company value using 130 Indonesian firms with a period 2004 to 2006. Yaputra and Prasetyo (2012) found a positive relationship between intellectual and corporate value companies using listed firms in the category of infrastructure, utility and transport with period 2008 to 2010 . Some conclusions derived from previous studies are as follow: (1) intellectual capital is not only increases firm value but also increases organisational value (Bontis, Chong Keow and Richardson, 2000), (2) 
physical capital efficiency is the most significant factor in affecting firm value and increasing firm' s productivity compared to other factors of intellectual capital in developing countries (Gan and Saleh, 2008; Chan, 2009), (3) human capital is the main factor in affecting firm value in most European countries particularlty Greece (Maditinos et al., 2011).

Finally, to answer the research question, and based on the previous study findings, hence, a series of testable hypothesis for intellectual capital are derived as follow:

Edvinsson and Malone (1997), Chen et al. (2005), Tan et al. (2007) and Switzer and Huang (2007) find a postive relationship between intellectual capital and firm performance, hence this study hypothesised that:

1. Human capital efficiency, structural capital efficiency, capital employed efficiency and innovation capital efficiency have a positive impact on firm performance

\section{Value added intellectual capital (VAIC) has a positive impact on firm performance}

In conclusion, most previous studies conducted in Indonesia yielded relatively inconsistent results. For example, Darmadi (2011) conducted series of studies using the same data from 2005 to 2007 but different data types, one study used panel data and other study used cross sectional data, and also using the same data but different sample (number of observations used), however the results found apparently inconsistent. Hence, no conclusion can be derived from previous studies in Indonesia. Therefore, this study attempts to investigate the impact of corporate governance and intellectual capital on firm performance using a carrefully crafted econometric techniques, extensive data period and large number of observations compared to those previous studies conducted in Indonesia.

\section{Data and Methodology}

This study uses data from the quarterly report of Indonesian-listed firms for the period of 2009-2013 collected from Indonesian Stock Exchange (IDX) archive. In the end of 2013, there are 464 listed firms in the Indonesian Stock Exchange. There are nine industrial categories in IDX; (1) Crops Industry, (2) Coal Mining Industry, (3) Basic Industry and Chemical Industry, (4) Machinery and Heavy Equipment Industry, (5) Consumer Goods Industry, (6) Property, Real Estate and Building Construction Industry, (7) Infrastructure, Utilities and Transportation Industry, (8) Finance Industry, (9) Trade, Services and Investment Industry, and firms in the category of finance industry are dropped, and hence only eight categories of industry will be employed in this study.

From 464 listed-firms, only 74 firms are included on the financial category, and hence there are 390 listed firms. Afterwards, only firms that listed before 2009 are included or at least have five years of annual report; 390 firms is substracted with 89 firms listed after 2009, so there are only 301 firms that are included as population. Using Isaac dan Michael formulation in determining the sample used, therefore, a balanced panel data of 120 listed firms are employed in this study from the period of 2009 to 2013. Though only 120 firms were included, the sample may do well in capturing aggregate condition in the country 


\section{Macrothink}

Research in Applied Economics

ISSN $1948-5433$

2016, Vol. 8, No. 1

because the listed firms can represent the whole industry in Indonesia as the 120 listed firms are drawn proportionally from each industries using simple random sampling technique.

Variables are largely adopted from previous study, thus this study uses two firm performance proxies as the dependent variables which are Tobins' $Q$ and Return on Assets (ROA). The explanatory variables include two parts, corporate governance variables and intellectual capital variables. Corporate governance variables include commissioners, independent commissioners, directors, independent directors, etnic, and the education level (high school, undergraduate, graduate level), while intellectual capital variables include human capital efficiency (HCE), structural capital efficiency (SCE), capital employed efficiency (CEE) and innovation capital efficiency (INCE). While firm size, industrial categories (industry dummy) and ownership status (government, private and foreign status) serve as control variables.

Variables are defined as follow: Tobins' $Q$ is measured as ratio of market value of equity and book value of long term debt over total assets; Return on Asset is measured as ratio of net income over total assets; commissioners is measured as the total number of commissioners; independent commissioners is measured as the percentage of independent commissioners over total commissioners; directors is measured as the total number of directors; the independent directors is measured as the percentage of independent directors over total directors; etnic of directors is measured as the etnic of chief director; the education level is measured as the education level of chief director; intellectual capital is measured as value added intellectual capital (VAIC) which is derived from: $V A I C=\frac{V A}{H C}+\frac{S C}{V A}+\frac{V A}{C E}+\frac{I N C}{V A}$ or $V A I C=H C E+S C E+C E E+I N C E$

Value Added $(V A)=$ Net sales revenue - cost of good sold - depreciation

Human Capital $(H C)=$ Total expenditures on employees

Human Capital Efficiency $(H C E)=\frac{V A}{H C}$

Structural Capital $(S C)=V A-H C$

Structural Capital Efficiency $(S C E)=\frac{S C}{V A}$

Capital Employed $(C E)=$ Physical capital + financial assets atau total asset - intangble asset

Capital Employed Efficiency $=\frac{V A}{C E}$

Innovation Capital $(I N C)=$ Total $R \& D$ Expenditures

Innovation Capital Efficiency $(I N C E)=\frac{I N C}{V A}$ 
Table 1. Variables

\begin{tabular}{lll}
\hline Variables & Indicators \\
\hline Dependent & Firm Performance & Tobins' Q \\
& & ROA \\
\hline Independent & Corporate Governance & Number of Board Commissioners \\
& & Independent Commisioners \\
& Number of Board Directors \\
& Independent Directors \\
& Director's Etnic \\
& Director's Graduate Origin \\
& Director's Qualifications \\
& Director's Remuneration \\
& Human Capital Efficiency (HCE) \\
& Intellectual Capital & Stuctural Capital Efficiency (SCE) \\
& & Capital Employed Efficiency (CEE) \\
& Innovation Capital Efficiency (INCE) \\
& Value Added Intellectual Capital (VAIC) \\
\hline
\end{tabular}

This study uses panel data which allows the unobservable heterogeneity for each observation in the sample to be eliminated and multicollinearity among variables to be alleviated. This study employs two equation models, first equation for Tobins' $\mathrm{Q}$, and second equation for ROA. Ordinary Least Square (OLS) is used for specification testing, and to estimate the firm performance (Tobins' Q and ROA), this equation is the first point to begin, the model is as follows:

$y_{i t}=\alpha+x_{i t}^{\prime} \beta+\cdots+x_{i n}^{\prime} \beta_{n}+u_{i t}$

$u_{i t}=\mu_{i}+\lambda_{t}+v_{i t}$

$i=1, \ldots, N ; t=1, \ldots, T$

Where $\mu_{i}$ denotes the unobservable individual effect, $\lambda_{t}$ denotes the unobservable time effect, and $v_{i t}$ is the remainder stochastic disturbance term. When using the Ordinary Least Squares (OLS) to estimate $\beta$, one assumes that $x_{i t}^{\prime}$ is orthogonal with $u_{i t}$ of equation (1), but this may not be true, and thus the estimated $\beta$ may be biased with endogeneity. Hence, Table 1 provides specification tests results. 
Table 2. Specification Testing Results

\begin{tabular}{|c|c|c|c|}
\hline \multicolumn{2}{|c|}{ Specification Tests } & \multirow{2}{*}{$\frac{\text { Tobins }^{\prime} \boldsymbol{Q}}{0,9712}$} & \multirow{2}{*}{$\frac{\boldsymbol{R} \boldsymbol{O} \boldsymbol{A}}{0,0000}$} \\
\hline \multirow{4}{*}{ IM-Test } & Skewness & & \\
\hline & Kurtosis & 0,3150 & 0,0156 \\
\hline & Heteroskedasticity & 1,0000 & 0,0000 \\
\hline & Total & 1,0000 & 0,0000 \\
\hline VIF & Multicollinearity & 1,3900 & 1,3900 \\
\hline NL Check & Linearity & 0,0107 & 0,0000 \\
\hline Hausmann & Endogeneity & 0,0328 & 0,0513 \\
\hline \multicolumn{2}{|c|}{ Final Equation Model } & Non_lin IV 2SLS & Non-Lin GMM \\
\hline
\end{tabular}

As can be seen in Table 2, linearity and endogeneity appear to raise concern for Tobins' Q, and heteroskedasticity, linearity and endogeneity are major problems for ROA. Further, the Durbin-Wu-Hausman test for endogeneity is necessary, and the result confirms that firm size, age and experience are indeed endogenous for independent commissioners and independent directors, and those variables are employed as Instrumental Variabel (For endogeneity test, see Table 2). Hence, the equations employed for Tobins' $Q$ and ROA are non linear GMM and non linear IV 2SLS subsequently. Therefore, the instrumental variable (IV), denoted as $z$, approach may be used to solve the endogeneity; while the changes in the new IV are associated with changes in $x$ but do not lead to changes in $y$ (except indirectly via $x$ ). Therefore, the equation which includes endogeneity is specified as follows (Cameron \& Trivedi, 2010);

$y_{1 i}=y_{2 i}^{\prime} \beta_{1}+x_{1 i}^{\prime} \beta_{2}+\cdots+x_{n i}^{\prime} \beta_{n}+u_{i}, \quad i=1, \ldots, N$

The regression errors $u_{i}$ are assumed to be uncorrelated with $x_{1 i}^{\prime}$ and $x_{n i}^{\prime}$ but correlated with $y_{2 i}^{\prime}$, and this correlation leads to an inconsistent estimation. To obtain a consistent estimation, a reduced-form model is appropriate;

$y_{i}=x_{1 i}^{\prime} \beta_{1}+\cdots+x_{n i}^{\prime} \beta_{n}+u_{i}$

$e=\left(u_{i} \mid z_{i}\right)=0$

The regression model is specified as follows:

Firm Performance $_{i t}=\beta_{0}+$ Commissioner $_{i t}+$ Independent Commissioner $_{i t}+$ Directors $_{i t}+$ Independent Directors $_{i t}+$ Gender $_{i t}+$ Etnic $_{i t}+$ Graduate Origin $_{i t}+$ Education_HighSchool $_{i t}+$ Education_Undergraduate $_{i t}+$ Education_Graduate $_{i t}+$ Remuneration $_{i t}+H C E_{i t}+S C E_{i t}+C E E_{i t}+I N C E_{i t}+V A I C_{i t}+$ Government $_{i t}+$

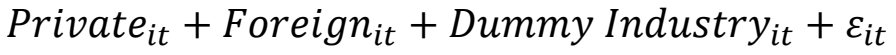




\section{Empirical Results}

Table 3 provides descriptive statistics and Table 3 provides regression results. As can be seen in Table 3, The mean value of Tobins' $Q$ is 10.0547 with a range of -1.7660 to 16.3760 , suggesting that the majority of the firms have higher performance. Tobins' high Q indicates that the stock price is rated higher than the book values (overvalued). The stock is considered overvalued often happen to firms that do not have a stable income and return on equity and, low growth of revenue compared to the average growth of the market. The mean value of ROA is $5.43 \%$ with a range from $-172 \%$ to $877 \%$. Although the mean value of ROA is relatively small but it is positive, indicationg that the firms in the sample can create value for shareholders within the time period of this study. Positive value also indicates that the assets of the company has been effectively used in generating surplus revenues. Low value of ROA, may indicate that most of firms are asset-intensive firms. If so, then the firms need more funds to be invested in the business in order to generate higher revenues. Based on common rule, if the value of ROA is less than $5 \%$ then it may indicate that the company is a company based assets (asset-heavy firms), for example, manufacturing companies, telecommunications companies, transportation companies, and others; while if the value of ROA is greater than $20 \%$ then it may indicate that the company is asset-light firms, as an example of advertising companies, software companies, and others. It can be concluded that the firms used as sample are mostly asset-heavy industry.

The mean value of total commissioner is 4.7164 with a range of 2,000 to 22,000, indicating that few firms in sample are having smaller number of commissioners compared to the average number of commissioners owned by most firms included in the sample. The mean value of independent commissioners is 0.3842 with a range of 0,000 to 1,000 , indicating that few firms in sample are having smaller number of independent commissioners compared to the average number of independent commissioners owned by most firms included in the sample.

The mean value of directors is 5.0822, with a range of 2.0000 to 13,000 , indicating that most firms have a relatively small number of directors compared to the average number of directors in the sample. The mean value of independent directors is at 0.1654 with a range of 0.000 to 1.0000 , suggesting that most firms in sample have smaller number of independent directors. The mean value of gender is $97,10 \%$ male directors, this is equal to 116 firms out of total sample (120 firms), indicating that the majority of directors are dominated by male directors. The mean value of age of director is 53,8 with a range of 32 to 75 , indicating that most of directors appointed are those who are at mature age. The mean value of ethnic is 0,8299 which is equal to 100 firms out of total sample (120 firms), indicating that majority of directors' ethnic is Indonesian citizen. The mean value of graduate origin is $48,26 \%$ which is equal to 58 firms out of total sample (120 firms), suggesting that nearly half of directors graduate from Indonesian Education Institution (domestic university). 
Table 3. Descriptive Statistics

\begin{tabular}{lcrrrr}
\hline Variables & Obs & \multicolumn{1}{c}{ Mean } & Std. Dev & \multicolumn{1}{c}{ Min } & \multicolumn{1}{c}{ Max } \\
\hline Tobins' Q & 2280 & 10,0547 & 2,9728 & $-1,7660$ & 16,3760 \\
ROA & 2280 & 0,0543 & 0,2161 & $-1,7290$ & 8,7330 \\
Commissioners & 2280 & 4,7164 & 2,4950 & 2,0000 & 22,0000 \\
Independent Commissioners & 2280 & 0,3842 & 0,1527 & 0,0000 & 1,0000 \\
Directors & 2280 & 5,0822 & 1,8701 & 2,0000 & 13,0000 \\
Independent Directors & 2280 & 0,1654 & 0,1400 & 0,0000 & 1,0000 \\
Age & 2280 & 53,8800 & 7,5081 & 32,0000 & 75,0000 \\
Etnic (Dummy) & 2280 & 0,8299 & 0,3758 & 0,0000 & 1,0000 \\
Graduate_Origin (Dummy) & 2280 & 0,4826 & 0,4998 & 0,0000 & 1,0000 \\
Education_HighSchool (Dummy) & 2280 & 0,0690 & 0,2535 & 0,0000 & 1,0000 \\
Education_Undergraduate (Dummy) & 2280 & 0,4857 & 0,4999 & 0,0000 & 1,0000 \\
Experience & 2280 & 6,0818 & 6,2517 & 0,0000 & 26,0000 \\
Remuneration & 2280 & 18504 & 58751 & 21,0000 & 930844 \\
Human Capital Efficiency (HCE) & 2280 & 0,4821 & 0,1720 & $-0,5489$ & 2,1000 \\
Structural Capital Efficiency (SCE) & 2280 & 0,7494 & 0,0745 & $-0,3070$ & 1,7000 \\
Capital Employed Efficiency (CEE) & 2280 & 0,4121 & 0,7006 & $-2,3280$ & 16,4290 \\
Innovation Capital Efficiency (INCE) & 2280 & $-0,0001$ & 0,0042 & $-0,2000$ & 0,0170 \\
VAIC & 2280 & 13,2696 & 2,1394 & 4,0780 & 21,2660 \\
Firm Size (Log) & 2280 & 14,7472 & 1,8686 & 8,6840 & 20,8190 \\
Government (Dummy) & 2280 & 0,0667 & 0,2495 & 0,0000 & 1,0000 \\
Private (Dummy) & 2280 & 0,7263 & 0,4459 & 0,0000 & 1,0000 \\
Foreign (Dummy) & 2280 & 0,2070 & 0,4053 & 0,0000 & 1,0000 \\
Industry_1 (Dummy) & 2280 & 0,1169 & 0,3214 & 0,0000 & 1,0000 \\
Industry_2 (Dummy) & 2280 & 0,1002 & 0,3004 & 0,0000 & 1,0000 \\
Industry_3 (Dummy) & 2280 & 0,1837 & 0,3874 & 0,0000 & 1,0000 \\
Industry_4 (Dummy) & 2280 & 0,0835 & 0,2767 & 0,0000 & 1,0000 \\
Industry_5 (Dummy) & 2280 & 0,1349 & 0,3417 & 0,0000 & 1,0000 \\
Industry_6 (Dummy) & 2280 & 0,0585 & 0,2347 & 0,0000 & 1,0000 \\
Industry_7 (Dummy) & 2280 & 0,1218 & 0,3271 & 0,0000 & 1,0000 \\
Industry_9 (Dummy) & 2280 & 0,2004 & 0,4004 & 0,0000 & 1,0000 \\
\hline & & & & &
\end{tabular}

The mean value of education for high school is $6,9 \%$, suggesting that only $6,9 \%$ of the chief directors have high school qualification. The mean value of education for undergraduate is $48,67 \%$, indicating that only $48,67 \%$ of chief directors have undergraduate qualification, and nearly $50 \%$ of chief directors have graduate qualification. The mean value of experience is 6 with a range of 0 to 26, suggesting that the majority of chief directors have 6 years experience as chief directors. The mean value of remuneration is 18,504 with a range of 21,000 to 930,844 , suggesting that the majority of chief directors have relatively low remuneration. The value of human capital efficiency is 0.4821 . Human Capital is an indicator of the size of economic value of human resource capacity. Education, experience and capabilities of human resources can be 
assessed economically, indicating that the higher the value of human capital, the higher the quality of human resources as an assets in the company. The mean value of structural capital efficiency is 0.7494 . Structural capital includes infrastructure, better processing technology and goods, database companies, trademarks, and others that can be measured by economic value, suggesting that the higher the value of structural capital, the higher the firms' economic value as indicated by infrastructure/process/database/trademark and many others. The mean value of capital employed efficiency is 0.4121 with a range of 16.4290 to 2.3280 , indicating that most firms do not utilise all resources optimally in generating income. The mean value of innovation capital efficiency is -0.0001 with a range of -0.2000 to 0.0170 , suggesting that innovation funding for research and development is relatively low for most firms in the sample. The mean value of Value Added Intellectual Capital (VAIC) is 13.2696 with a range of 4.0780 to 21.2660 , indicating that most firms have relatively been able to create value added in terms of intellectual capital so that the company can grow and develop. The mean value of firm size is 14.7472 with a range of 8.6840 to 20.8190 , indicating that most firms in the sample relatively large firms. The mean value of government, private and foreign ownership status is $6.67 \%$, $72.63 \%$ and $20,7 \%$ subsequently. There are eight industrial categories used in this study, the total sample for the industry one, two, three and four is 14 companies (12\%), 12 companies $(10 \%), 22$ companies (18\%) and 10 companies ( $8 \%)$ subsequently. Further the total sample for the industry five, six, seven and nine is 16 companies (14\%), 7 companies (6\%), 15 firms (12\%) and 24 companies $(20 \%)$.

Table 4 provides regression results, and as can be seen that the coefficient of commissioners is a negative and significant, which confirms that higher number of total commissioners is associated with lower firm performance as measured by Tobins' Q. The result is contradictory with the hypothesis which stated that the number of board commisioners has a positive impact on firm performance. This result is also not consistent with Carter Simkins \& Simpson (2003) and Coles, Daniel \& Naveen (2008). This is probably due to the total number of commissioners in the sample range from 2 to 22 , but only one firm has 22 commissioners on the board. Indeed, firms having commissioners range from 2 to 11 are 43 firms with the most frequent value is three. The minimum number of commissioners that should sit on the board is three as stipulated by the corporate governance guidelines conduct. Nevertheless, there are 13 firms in sample having two commissioners on the board. The negative result may be due to the fact that most firms are owned by group or family group, hence the possibility of expropriation is higher, therefore, a country who adopts a two-tier board system is advised to have a more independent commissioner in the board of commissioners to minimise the conflict of interest. Moreover, the skills and experience of independent commissioners employed should match the nature, scale and technical complexity of the issues on which a decision is being made, however, this is not the case in most firms in Indonesia, hence a negative impact is yielded. Further, the large number of board size will result in higher cost of agency problems and also affect in changing the role of board directors into mere figurative role in which the role of this figure is only supplemental of the existing directors on board. 


\section{Mll Macrothink}

Table 4. Regression Results

\begin{tabular}{|c|c|c|c|c|c|c|}
\hline \multirow{2}{*}{ Variables } & \multicolumn{3}{|c|}{ Tobins' $Q$} & \multicolumn{3}{|c|}{$R O A$} \\
\hline & Coefficient & Std. Err. & $P>z$ & Coefficient & Std. Err. & $P>|z|$ \\
\hline Constant & 11,4160 & 16,3420 & 0,4850 & 0,0061 & 0,2225 & 0,9780 \\
\hline Commissioners & $-0,2988$ & 0,1706 & 0,0800 & 0,0041 & 0,0051 & 0,4190 \\
\hline Independent Commissioners & $-40,0105$ & 33,6597 & 0,2350 & $-0,4244$ & 0,5697 & 0,5460 \\
\hline Directors & 1,4827 & 0,6464 & 0,0220 & $-0,0037$ & 0,0198 & 0,8520 \\
\hline Independent Directors & 24,9461 & 21,7074 & 0,2500 & $-0,1750$ & 0,5075 & 0,7300 \\
\hline Etnic & 2,1445 & 1,5012 & 0,1530 & 0,0076 & 0,0366 & 0,8350 \\
\hline Graduate_Origin & $-0,8838$ & 0,9539 & 0,3540 & 0,0259 & 0,0256 & 0,3110 \\
\hline Education_HighSchool & 3,6853 & 1,3080 & 0,0050 & $-0,0003$ & 0,0468 & 0,9940 \\
\hline Education_Undergraduate & $-0,0909$ & 0,5451 & 0,8680 & 0,0187 & 0,0228 & 0,4140 \\
\hline Education_Graduate & 0,0000 & 0,0000 & 0,0000 & 0,0000 & 0,0000 & 0,0000 \\
\hline Remuneration & $-1,9200$ & 0,3050 & 0,9500 & 0,1220 & 0,9470 & 0,1970 \\
\hline $\mathrm{HCE}$ & $-1,1300$ & 0,8600 & 0,1890 & 0,2100 & 0,4540 & 0,6440 \\
\hline SCE & $-1,7900$ & 0,6020 & 0,7660 & 0,3600 & 0,1300 & 0,7820 \\
\hline CEE & 0,3714 & 0,1999 & 0,0630 & 0,0458 & 0,0091 & 0,0000 \\
\hline INCE & $-7,8888$ & 17,9854 & 0,6610 & 0,7102 & 1,0351 & 0,4930 \\
\hline Intellectual Capital/VAIC & 0,0663 & 0,0973 & 0,4950 & 0,0077 & 0,0063 & 0,2200 \\
\hline Government & $-0,9114$ & 1,2190 & 0,4550 & $-0,0104$ & 0,0501 & 0,8350 \\
\hline Private & $-0,6174$ & 1,4950 & 0,6800 & 0,0168 & 0,0573 & 0,7690 \\
\hline Foreign & 0,0000 & 0,0000 & 0,0000 & 0,0000 & 0,0000 & 0,0000 \\
\hline Industry 1 & 2,1672 & 1,9481 & 0,2660 & 0,0216 & 0,0464 & 0,6420 \\
\hline Industry 2 & 2,9115 & 2,3788 & 0,2210 & $-0,0242$ & 0,0611 & 0,6910 \\
\hline Industry 3 & 0,4615 & 1,7302 & 0,7900 & 0,0742 & 0,0523 & 0,1560 \\
\hline Industry 4 & $-0,4251$ & 1,7143 & 0,8040 & 0,0344 & 0,4795 & 0,4720 \\
\hline Industry 5 & 0,9354 & 1,5629 & 0,5490 & 0,0807 & 0,0413 & 0,0510 \\
\hline Industry 6 & $-0,9364$ & 2,1406 & 0,6620 & 0,0128 & 0,0554 & 0,8170 \\
\hline Industry 7 & 1,0727 & 1,9281 & 0,5780 & 0,0135 & 0,0391 & 0,7300 \\
\hline Industry 9 & 0,0000 & 0,0000 & 0,0000 & 0,0000 & 0,0000 & 0,0000 \\
\hline
\end{tabular}

The coefficient of independent commisioners is a negative and not significant, suggesting that higher number of total independent commissioners is associated with lower firm performance. The result is inline with the hypothesis which stated that the independent commisioners has a negative impact on firm performance. Nevertheless, the non significant result indicating that there is no impact of independent commissioners' existence on firm performance. This result is consistent with Agrawal and Knoeber (1996), Yermack (1996), Klein (1998), Bhagat and Black (2002) and Drakos and Bekiris (2010). Every firm has specific procedures and requirements in the appointment/selection of independent commisioners that should comply to the corporate governance guidelines promulgated by the government. However, few firms select the independent commisioner based on kinship or collegues. It is 
also common that independent commisioners are selected from those who occupied certain position in the government institutions or private institutions. Apparently, there are independent commissioners who served as independent commissioners on several firms. Hence, the large number of independent commissioners will only add burden to the company. In the end, the existence of independent commisioners is merely simbolic position to meet the corporate governance guidelines set by the government, and in the end, their existence do not bring a positive and significant impact on improving firm performance or firm value.

The coefficient of directors is a positive and significant, suggesting that higher number of total directors is associated with higher firm performance as measured by Tobins' $\mathrm{Q}$. The result is inline with the hypothesis which stated that the number of board directors has a positive impact on firm performance. This result is also consistent with Carter Simkins \& Simpson (2003) and Coles, Daniel \& Naveen (2008). The positive result is supported by the data in sample that most firms have 2 to 13 directors, and from total sample, there are 54 firms who have 5 directors on board. The result is consistent with (Coles, Daniel \& Naveen, 2008). Morevoer, the positive impact may be due to the fact that most firms are owned by group or family group and it provides higher chances for family to sit on board, hence they will act on the best interest of owners and will speak as one voice and often has a proactive manager that also speaks with one combined voice for the organisation. This adds benefits because the manager and the board are on the same page and speak with a single voice. Moreover, the directors on board are proactive in taking advantage of emerging opportunities and is especially valuable for entrepreneurial businesses. This is also may explain the contrary result between commisioners and directors' existensy impact on firm performance.

The coefficient of independent directors is a positive and not significant, suggesting that higher number of total independent directors is associated with higher firm performance as measured by Tobins' Q. The result is contradictory with the hypothesis which stated that independent directors has a negative impact on firm performance. This result is also not consistent with Agrawal and Knoeber (1996), Yermack (1996), Klein (1998), Bhagat and Black (2002) and Drakos and Bekiris (2010). However, the non significant result indicating that there is no impact of independent directors' existence on firm performance. The result is consistent with Hermalin and Weisbach 1991). Although the board of directors (both commissioners and directors) plays an important role in maintaining the effectiveness of corporate governance, but the large number of directors is likely to affect the cost of coordination, so that if these costs are not accommodated well, it will actually disrupt the effectiveness of supervision by firm's management (Garg, 200; Rose, 2007). The result is not consistent with agency theory perspective, that the greater the size of the board of directors, the greater the likelihood of the agency problem as more and more people who will be involved in the process of monitoring and review of the actions/decisions made by management (Coles, Daniel \& Naveen, 2008). Further, independent directors appointed at least should (1) possess integrity and relevant industrial expertise, (2) not have any material or pecuniary relationship with the company or its subsidiaries, (3) should not have any relationship (kinship) with firms' owners, then they do not have to pander to other management personnel in order to retain their jobs, and they will have an objective view of the firms' health and operations. Thus, 
failure to fill at least three requirements of independent directors may impact on their performance in improving firm performance.

The coefficient of ethnic is a positive and not significant, suggesting that there is no impact of ethnic differences on firm performance, and this is consistent with Hambrick et al. (1996) and Carter et al. (2003). The result is inline with the hypothesis which stated that ethnic has a positive impact on firm performance. Ethnic diversity offers greater innovativeness, greater creativity, quality decision making and eventually greater financial performance, however, the non significant result may be due to the fact that the number of foreign directors is relatively small, hence it makes no difference on firm performance.

The coefficient of graduate origin is a negative and not significant, suggesting that higher number of directors graduate from domestic education institution is associated with lower firm performance. The result is contradictory with the hypothesis which stated that the graduate origin has a positive impact on firm performance. Nevertheless, the non significant result indicating that there is no impact of graduate origin on firm performance. The result is also in contrast with Switzer and Huang (2007), Chang, Dasgupta and Hilary (2010) and Darmadi (2011) that firm value is higher when firms have directors who have a qualitification from top universities. However, it does not indicate that directors who graduate from domestic university will lower the quality of management compared to foreign graduates.

The coefficient of education_HighSchool is a positive and significant, suggesting that chief director who has high school qualification has an impact on improving firm performance. The result is inline with the hypothesis which stated that qualification has a positive impact on firm performance. The coefficient of education_Undergraduate is a negative and not significant, suggesting that chief director who has undergraduate qualification has no impact on firm performance. The result is contradictory with the hypothesis which stated that qualification has a positive impact on firm performance. The coefficient of education_Graduate is a positive and not significant, suggesting that chief director who has graduate qualification has no impact on improving firm performance. The result is inline with the hypothesis which stated that qualification has a positive impact on firm performance. This result is also consistent with Switzer and Huang (2007) and Chang, Dasgupta and Hilary (2010). It can be concluded that directors who have lower qualification have a significant impact on firm performance. This peculiar finding may be due to the fact that most directors are at matured age (see the mean value of directors' age which is 53 with a range of 32 to 75), and though they only have high school qualification but they have considerable experiences as directors (see the mean value of experience is 6 years with a range of o to 26 years). In addition, most aged-directors are founding fathers and/or first generation successors, therefore, they know the details in running firm's management.

The coefficient of remuneration is a negative and not significant, suggesting that remuneration has no impact on firm performance. The result is contradictory with the hypothesis which stated that remunaration has a positive impact on firm performance. This is also not consistent with Aggarwal and Samwick (1999) and Dong and Ozkan (2008). The non significant result may be due to relatively low amount of remuneration which is only 18 with 
a range of 21 to 93. In addition, when directors are appointed based on cronyism and paid regardless of the firm's performance, then remuneration will affect negatively on firm performance.

The coefficients of human capital efficiency, structural capital efficiency and innovation capital efficiency are negative and not significant, suggesting that human capital efficiency, structural capital efficiency and innovation capital efficiency have no impact on firm performance. The result is contradictory with the hypothesis which stated that human capital efficiency, structural capital efficiency and innovation capital efficiency have a positive impact on firm performance. The result is inconsistent with Kuryanto and Syaffrudin (2008) who found no significant relationship between intellectual capital and firm value in Indonesia. However, coefficient of capital employed efficiency is positive and significant, suggesting that capital employed efficiency has an impact in improving firm performance. In developing countries, intellectual capital has not come to its popularity yet, therefore only capital employed efficiency is important matter for investors. Overall, the coefficient of value added intellectual capital (VAIC) is a positive and not significant, suggesting that VAIC has no impact on improving firm performance. The result is inline with the hypothesis which stated that intellectual capital has a positive impact on firm performance. The result is consistent with Edvinsson and Malone (1997), Chen et al. (2005), Tan et al. (2007) and Switzer and Huang (2007).

The coefficients of government and private ownership status are negative and not significant, suggesting that ownership status has no impact on firm performance. The coefficient of foreign ownership status is positive and not significant, suggesting that foreign ownership status has no impact on firm performance. In addition, there is no difference on firm performance as the result of corporate governance conduct and intellectual capital for all industry categories.

\section{Conclusions}

In the last eight decades, there has been considerable theoretical emphasis on corporate governance mechanisms and intellectual capital. This paper is an attempt to empirically test for corporate governance and intellectual capital in the Indonesian context in which this study examines a recent dataset of Indonesian listed-firms. Using non linear GMM and non linear IV 2SLS for Tobins' Q and ROA subsequently, this study demonstrates that controlling for heteroskedasticity, linearity and endogeneity in the corporate governance and intellectual capital equation slightly increases the estimated coefficients. Therefore, OLS estimates are upward-biased, but the bias is not so large as to be concern. Additionally, this study demonstrates that using valid or non-weak instruments (firm size, experience and age), leads to precise estimates of the corporate governance and intellectual capital coefficients. The result reveals that all variables, apart from commissioners, directors, education-highschool and capital employed efficiency exhibit a non significant impact on Tobins'Q, while all variables are statistically non significant for ROA. The empirical evidence is less conclusive than that of previous studies in developed countries. In conclusion, an effective corporate governance can increase firm value, indeed, most listed-firms are merely comply to the 
regulations set; the corporate governance conduct is not based on awareness of good corporate governance as basic needs, hence it will not become a part of firm's culture. In addition, complicated bureaucracy and weak of law enforcement systems in Indonesia also add complexity in implementing good corporate governance. The contradictory results conducted on previous studies are restricted to different methods, time frame and scope of the sample used. It should also be noted that this study has only covered the period from 2009 to 2013, with a sample of 120 firms out of Indonesian-listed firms; hence, the validity of the findings interpreted in this study are limited to the scope of the data and the condition of economics for the period of the data.

\section{Acknowledgements}

The authors are grateful to the anonymous referees of the journal for their extremely useful suggestions to improve the quality of the article. Usual disclaimers apply.

\section{References}

Aggarwal, R., \& Samwick, A. (1999). The other side of the trade-off: The impact of risk on executive compensation. Journal of Political Economy, 107, 65-105. http://dx.doi.org/10.1086/250051

Agrawal, A., \& Knoeber, C. R. (1996). Firm performance and mechanisms to control agency problems between managers and shareholders. Journal of Financial and Quantitative Analysis, 31(3), 377-397. http://dx.doi.org/10.2307/2331397

Anderson, R., \& Bizjak, J. (2003). An empirical examination of the role of the CEO and the compensation committee in structuring executive pay. Journal of Banking and Finance, 27(7), 1323-1348. http://dx.doi.org/10.1016/S0378-4266(02)00259-5

Barnhart, S. W., \& Rosenstein, S. (1998). Board composition, managerial ownership and firm performance: An empirical analysis. The Financial Review, 33(4), 1-16. http://dx.doi.org/10.1111/j.1540-6288.1998.tb01393.x

Bassi, L., \& Buren. M. V. (1999). Valuing investments in intellectual capital. International Journal of Technology Management, 18, 414-432.

Bhagat, S., \& Black, B. (2002). The non-correlation between board independence and long-term firm performance. Journal of Corporate Law, 27, 231-73.

Black, B. S., \& Kim, W. (2012). The effect of board structure on firm value: A multiple identification strategies approach using Korean data. Journal of Financial Economics, 104, 203-226. http://dx.doi.org/10.1016/j.jfineco.2011.08.001

Bontis, N. (1998). Intellectual capital: An exploratory study that develops measures and models. Management Decision, 36(2), 63-76. http://dx.doi.org/10.1108/00251749810204142 
Bontis, N., Chong Keow, W.C., \& Richardson, S. (2000). Intellectual capital and business performance in Malaysian industries. Journal of Intellectual Capital, 1(1), 85-100. http://dx.doi.org/10.1108/14691930010324188

Bornemann, M. (1999). Potential of value sistems according to the VAIC method. International of Journal of Technology Management, 18(5-8), 463-75.

Brown, L., \& Caylor, M. (2009). Corporate governance and firm operating performance. Review of Quantitative Finance \& Accounting, 32(2), 129-144. http://dx.doi.org/10.1007/s11156-007-0082-3

Bukh, P. N. (2003). The relevance of intellectual capital disclosure: A paradox? Accounting, Auditing \& Accountability Journal, 16(1), 49-56.

Cameron, A. C., \& Trivedi, P. K. (2010). Microeconometrics using stata (Rev. Ed.). College Station, Texas: Stata Press.

Carter, D. A., Simkins, B. J., \& Simpson, W. G. (2003). Corporate governance, board diversity, and firm value. Financial Review, 38, 33-53. http://dx.doi.org/10.1111/1540-6288.00034

Chan, K. H. (2009). Impact of intellectual capital on organisational performance, an empirical study of companies in the Hang Seng Index (part 1). The Learning Organization, 16(1), 4-12. http://dx.doi.org/10.1108/09696470910927650

Chang, Y.Y., Dasgupta, S., \& Hillary, G. (2010). CEO Ability, pay and firm performance. Management Science, 56(10), 1633-1652. http://dx.doi.org/10.1287/mnsc.1100.1205

Chen, M. C., Cheng, S. J., \& Hwang, Y. (2005). An empirical investigation of the relationship between intellectual capital and firms' market value and financial performance. Journal of Intellectual Capital, 6(2), 159-76. http://dx.doi.org/10.1108/14691930510592771

Cheung, Y. L., Stouraitis, A., \& Tan, W. (2010). Does the quality of corporate governance affect firm valuation and risk? Evidence from a corporate governance scorecard in Hong Kong. International Review of Finance, 10(4), 403-432.

Cheung, Y., Connelly, J. T., Limpaphayom, P., \& Zhou, L. (2007). Do investors really value corporate governance? Evidence from the Hong Kong market. Journal of International Financial Management and Accounting, 18(2), 86-122. http://dx.doi.org/10.1111/j.1467-646X.2007.01009.x

Choudhury, J. (2010). Performance impact of intellectual capital: A study of Indian IT sector. International Journal of Business and Management, 5(9), 72-80.

Claessens, S., Djankov, S., Fan, J. P. H., \& Lang, L. H. P. (2002). Disentangling the incentive and entrenchment effects of large shareholders. Journal of Finance, 57(6), 2741-2771. http://dx.doi.org/10.1016/S0304-405X(00)00067-2

Coles, J., Daniel, N., \& Naveen, L. (2008). Boards: Does One Size Fit All?, Journal of 
Financial Economics, 87, 329-356. http://dx.doi.org/10.1016/j.jfineco.2004.09.004

Connelly, J. T., Limpaphayom, P., \& Nagarajan, N. J. (2012). From versus substance: The effect of ownership structure and corporate governance on firm value in Thailand. Journal of Banking \& Finance, 36, 1722-1743.

Dalton, D., Daily, C., Johnson, J. L., \& Ellstrand, A. (1999). Number of directors and financial performance: A meta-analysis. Academy of Management Journal, 42, 674-686. http://dx.doi.org/10.2307/256988.

Darmadi, S. (2011). Board diversity and firm performance: The Indonesian evidence. Journal Corporate Ownership and Control, 8.

Darmadi, S. (2011). Do women in top management affect firm performance?, MPRA Paper. No. $38743 . \quad$ Retrieved from http://mpra.ub.uni-muenchen.de/38743/1/MPRA_paper_38743.pdf

Darmawati D., Khomsiyah \& Rahayu, R,G. (2005). Hubungan corporate governance dan prestasi perusahaan, Working Paper at Simposium Nasional Akuntansi VII.

Dehaene, A., De Vuyst, V., \& Ooghe, H. (2001). Corporate performance and board structure in Belgian companies. Long Range Planning, 34(3), 383-398. http://dx.doi.org/10.1016/S0024-6301(01)00045-0

Dittmar, A., \& Mahrt-Smith, J. (2007). Corporate governance and the value of cash holdings. Journal of Financial Economics, 83(3), 599-634. http://dx.doi.org/10.1016/j.jfineco.2005.12.006

Dong, M., \& A. Ozkan (2008). Institutional investors and director pay: An empirical study of UK companies. Journal of Multinational Financial Management, 18(1), 16-29. http://dx.doi.org/10.1016/j.mulfin.2007.06.001

Drakos, A., \& Bekiris, F. (2010). Corporate performance, managerial ownership and endogeneity: A simultaneous equations analysis for the Athens stock exchange. Research in International Business and Finance, 24, 24-38.

Drucker, P.F. (1993). Post-Capitalist Society. Butterworth Heinemann, Oxford.

Edvinsson, L., \& Malone, M.S. (1997). Intellectual Capital. London: Piatkus.

Edvinsson, L., \& Sullivan, P. (1996). Developing a model for managing intellectual capital. European Management Journal, 356-364. http://dx.doi.org/10.1016/0263-2373(96)00022-9

Gan, K., \& Saleh, Z. (2008). Intellectual capital and corporate performance of technology-intensive companies: Malaysia evidence. Asian Journal of Business and Accounting, 1(1), 113-30.

Garg, A. K. (2007). Influence of board size and independence on firm performance: A study of Indian companies. Vikalpa, 32(3), 39-60. 
Gompers, P., Ishii, J., \& Metrick, A. (2003). Corporate governance and equity prices. Quarterly Journal of Economics, 11(8), 107-155. http://dx.doi.org/10.1162/00335530360535162

Hambrick, D. C., Cho, T. S., \& Chen, M. (1996). The influence of top management team heterogeneity on firms' competitive moves. Administrative Science Quarterly, 41, 659-684. http://dx.doi.org/10.2307/2393871

Hanousek, J., Kocenda, E., \& Novotny, J. (2012). Firm efficiency: Domestic owners, coalitions, and FDI. Economic Systems, 36(4), 471-486. http://dx.doi.org/10.1016/j.ecosys.2012.04.004

Hanousek, J. Kocenda, E., \& Novotny, J. (2015). Corporate efficiency in Europe. Journal of Corporate Finance, 32, 32-40. http://dx.doi.org/10.1016/j.jcorpfin.2015.03.003

Harjoto, M. A., \& Hoje, J. (2008). Board leadership and firm performance. Journal of International Business \& Economics, 8(3), 143-154.

Herly, M., \& Sisnuhadi. (2011). Corporate governance and firm performance in Indonesia. International Journal of Governance, 1(2).

Hermalin, B. E., \& Weisbach, M. S. (1991). The effects of board composition and direct incentives on firm performance. Financial Management, 20, 101-112.

Hermalin, B. E., \& Weisbach, M. S. (2003). Board of directors as an endogenously determined institution. Federal Reserve Bank of New York Economic Policy Review, 9, $1-20$.

http://swa.co.id/corporate/gcg/ocbc-nisp-menerapkan-gcg-secara-substansial

https://en.wikipedia.org/wiki/accounting-scandals

Jensen, M. C., \& Meckling, W. H. (1976). Theory of the firm: Manajerial behaviour, agency costs and ownership structure. Journal of Financial Economics, 4, 305-360. http://dx.doi.org/10.1016/0304-405X(76)90026-X.

Klein, A. (1998). Firm performance and board committee structure. Journal of Law and Economics, 41, 275-99. http://dx.doi.org/10.1086/467391.

KNKG. (2013). Source from: http://www.knkg-indonesia.com/KNKG/index.asp

Kuryanto and Syaffrudin. (2008). Pengaruh Modal Intelektual Terhadap Kinerja Perusahaan. Simposium Nasional Akuntansi 11.

Lim, L. L. K., \& Dallimore, P. (2004). Intellectual capital: Management attitudes in service industries. Journal of Intellectual Capital, 5(1), 181-94. http://dx.doi.org/10.1108/14691930410512996

Maditinos, D., Chatzoudes, D., Tsairidis, C., \& Theriou, G. (2011). The impact of intellectual capital on firms' market value and financial performance. Journal of Intellectual Capital, 12(1), 132-51. http://dx.doi.org/10.1108/14691931111097944 
Mehralian, G., Rajabzadeh, A., Sadeh, M. R., \& Rasekh, H. R. (2012). Intellectual capital and corporate performance in Iranian pharmaceutical industry. Journal of Intellectual Capital, 13(1), 138-158.

Mitton, T. (2001). A cross-section analysis of the impact of corporate governance on the East Asian crisis. Journal of Financial Economics, 64(2), 215-241. http://dx.doi.org/10.1016/S0304-405X(02)00076-4

Mondal, A., \& Ghosh, S. K. (2012). Intellectual capital and financial performance of Indian banks, Journal of Intellectual Capital, 13(4), 515-530. http://dx.doi.org/10.1108/14691931211276115

Prassetyantoko, A. (2008). Corporate Governance Pendekaran Institusional, Jakarta: Gramedia Pustaka Utama.

Pudjiastuti, W., \& Mardiyah, A. A. (2007). The influence of board structure on firm performance, Simposium Nasional Akuntansi X, Unhas Makassar 26-28 Juli. Diambil dari: http://www.stie-mce.ac.id/ pdf/penelitian/N19990001075802.pdf

Roos, J., Roos, G., \& Edvinsson, L. (1998). Intellectual Capital - Navigating the New Business Landscape. Macmillan Press Ltd, UK.

Sami, H., Wang, J., \& Zhou, H. (2011). Corporate governance and operating performance of Chinese listed firms. Journal of International Accounting, Auditing dan Taxation, 20, 106-114. http://dx.doi.org/10.1016/j.intaccaudtax.2011.06.005

Schmid, M. M., \& Zimmermann, H. (2005). Should chairman and CEO be separated? leadership structure and firm performance in Switzerland. SSRN e-Library. Retrieved from http://ssrn.com/paper $=696381$

Shukeri, S. N., Shin, O., \& Shaari, M. S. (2012). Does board of directors; characteristics affect firm performance: Evidence from Malaysian public listed companies, International Business Research, 5(9).

Suherman, S., Rahmawati, W., \& Buchdadi, A. D. (2011). Firm performance, corporate governance and executive compensation in financial firms: Evidence from Indonesia, Working Papers.

Switzer, L., \& Huang, Y. (2007). How does human capital affect the performance of small and mid-cap mutual funds?, Journal of Intellectual Capital, 8, 666-681.

Tan, H.P., Plowman, D., \& Hancock, P. (2007). Intellectual capital and financial returns of

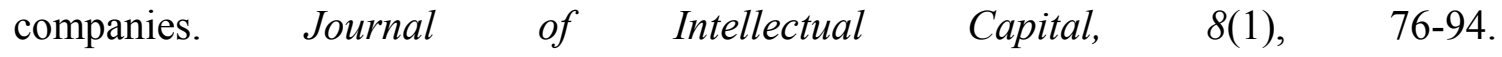
http://dx.doi.org/10.1108/1469193071071507

Tayles, M., Pike, R., \& Sofian, S. (2007). Intellectual capital, management accounting practices and corporate performance: Perceptions of managers. Accounting-Auditing and Accountability Journal, 20(4), 522-548. http://dx.doi.org/10.1108/09513570710762575

Ulum, I. (2008). Modal intelektual Perfomance Sektor perbankan di Indonesia. sumber: 
puslit2.petra.ac.id/ejournal/index.php/aku/article/.../17081/17034.

Yaputra, A., \& Prasetyo, A. H. (2012). Pengaruh modal intelektual terhadap kinerja keuangan perusahaan infrastruktur, utilitas dan transportasi yang terdaftar di Bursa Efek Indonesia Periode 2008-2010. Akuntansi Keuangan, 1(1), 88-103.

Yermack, D. (1996). Higher market valuation of companies with a small board of directors. $\begin{array}{llll}\text { Journal of Financial } & \text { Economics, } & \text { 40, }\end{array}$ http://dx.doi.org/10.1016/0304-405X(95)00844-5

Zahra, S. A., \& Stanton, W. W. (1988). The implications of board of directors composition for corporate strategy and performance. International Journal of Management, 5, 229-236.

\section{Copyright Disclaimer}

Copyright for this article is retained by the author(s), with first publication rights granted to the journal.

This is an open-access article distributed under the terms and conditions of the Creative Commons Attribution license (http://creativecommons.org/licenses/by/3.0/). 